\title{
Moringa oleifera, a new host record of Cercospora apii s. lat. from Uttar Pradesh, India
}

\section{Kumar $\mathbf{S}^{\mathbf{1}^{*}}$, Singh $\mathbf{R}^{2}$ and Saini DC ${ }^{\mathbf{1}}$}

\author{
${ }^{1}$ Birbal Sahni Institute of Palaeobotany, 53, University Road, Lucknow-226007(U.P.), India. \\ ${ }^{2}$ Department of Botany, D.D.U. Gorakhpur University, Gorakhpur-273009 (U.P.), India.
}

Kumar S, Singh R, Saini DC 2013 - Moringa oleifera, a new host record of Cercospora apii s. lat. from Uttar Pradesh, India. Plant Pathology \& Quarantine 3(1), 12-13, doi 10.5943/ppq/3/1/2

Cercospora apii s. lat. collected on living leaves of Moringa oleifera (Moringaceae) from Uttar Pradesh, India is a new host record. The fungus is described and illustrated.

Key words - Cercospora - Foliicolous hyphomycete - Fungi - Morphotaxonomy - New host record

\author{
Article Information \\ Received 11 February 2013 \\ Accepted 2 March 2013 \\ Published online 16 March 2013 \\ *Corresponding author: Shambhu Kumar - e-mail - skumartaxon@gmail.com
}

\section{Introduction}

Moringa oleifera Lam. belongs to family Moringaceae and is commonly called muringa or sahjan. It was introduced from tropical Asia or Malaysia in prehistoric times and is now pan tropic in cultivation, commonly found in India. The flowers and fruits are fried and used as a vegetable. It also has medicinal value as a blood purifier and for treatment of skin diseases, eye diseases, paralysis, antibiotic, scurvy, flatulence, galactagogue, dog bite, antispasmodic, hysteria, vulnerary, diuretic, rubefacient, counterirritant, neuralgia, earache, inflammation, caries, headache, palsy, rheumatism, gout, edema, dyspepsia and lumbago.

Due to its great significance in medicine, the plant has high demand but attack by the foliicolous fungus, Cercospora apii s. lat. causes serious foliar infection resulting in the death of leaves.

Upon critical morphological examination and comparison of morphological features with closely related fungi, the collection appears as a new host record of Cercospora apii s. lat..

\section{Methods}

The infected leaf samples were collected from Kusumhi forest, Gorakhpur during a field survey. Surface scrapping and free hand cut sections were taken through infection spots and mounted in lactophenol cotton-blue mixture for microscopic examination. Line drawings were done with the help of a camera lucida and measurement with micrometry. Specimens have been deposited in Herbarium Cryptogamiae Indiae Orientalis (HCIO), Indian Agriculture Research Institute (IARI), New Delhi and duplicates have been retained in the departmental herbarium for future reference. Morphological determinations have been done with the help of current literature pertaining to taxonomy of Cercospora. 


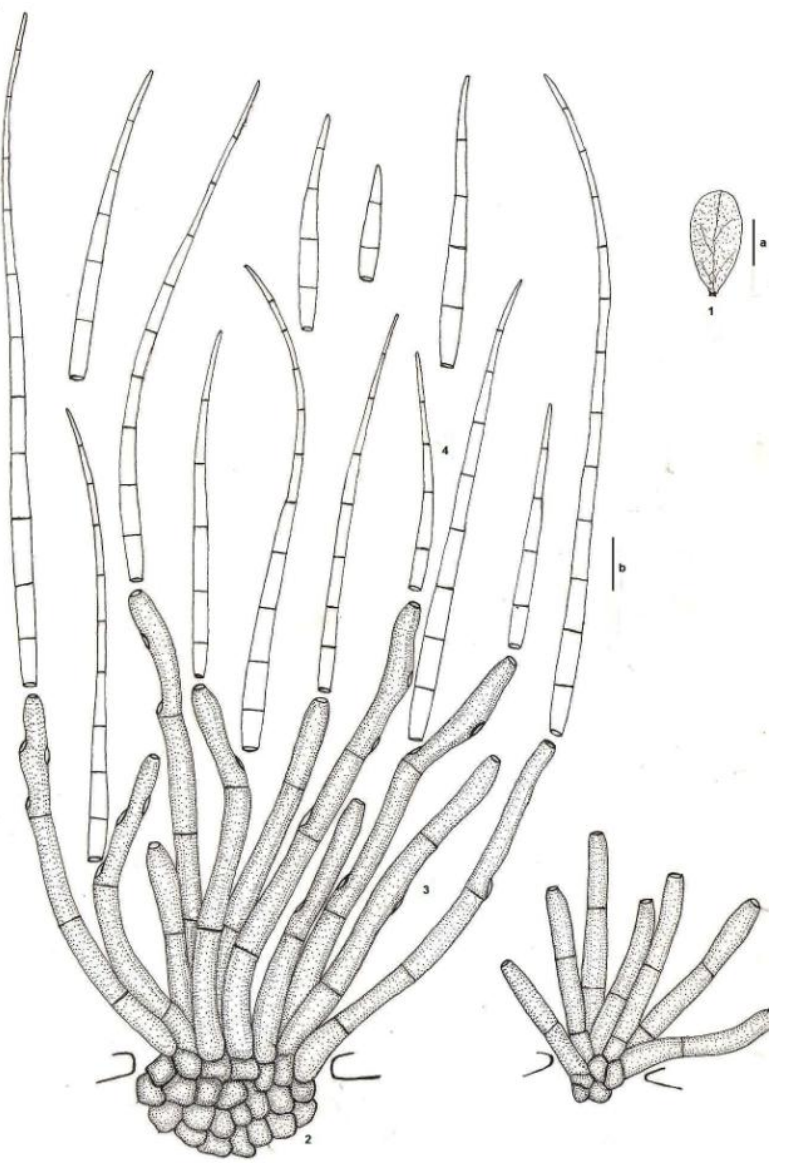

Fig. 1 - Cercospora apii s. lat. 1 Infection spots 2 Stromata 3 Conidiophores 4 Conidia. Bars $\mathrm{a}=20 \mathrm{~mm}, \mathrm{~b}=20 \mu \mathrm{m}$.

\section{Results}

\section{Taxonomy}

\section{Cercospora apii s. lat.}

Fig. 1

Infection spots amphigenous, circular to irregular, spreading on entire leaf surface, brown. Colonies amphiphyllous effuse. Mycelium internal. Stromata well developed, subepidermal, pseudoparenchymatous, olivaceous brown, 8-38 $\mu \mathrm{m}$ wide. Conidiophores macronematous, fasciculate (711 ), erect to procumbent, straight to flexuous, geniculate, smooth, thin-walled, unbranched, 1-3 euseptate, brown, 35-105 × 3-6 $\mu \mathrm{m}$ in diam. Conidiogenous cells integrated, terminal to intercalary, polyblastic, hilum thickened and darkened, (1.5-)2-3.5(-4.5) $\mu \mathrm{m}$ wide. Conidia solitary, simple, dry, acropleurogenous, smooth, thin-walled, 2-12 septate, straight to slightly curved, cylindrical to obclavatocylindrical, acicular, base truncate, apex rounded, hyaline, $25-145 \times 3-5 \mu \mathrm{m}$; hilum conspicuously thickened, (1.5-)2-3(-4.5) $\mu \mathrm{m}$ wide.

Material examined - On living leaves of Moringa oleifera Lam. (Moringaceae), Kusumhi Forest, Gorakhpur, (U.P.), India, 28 February 2008, coll. Shambhu Kumar, GPU Herb. No. KSR- 175, HCIO 48662.

\section{Discussion}

The circumscription of $C$. apii s. lat. has been given by Crous \& Braun (2003) followed by Kamal (2010). They suggested that the introduction of new names, for Cercospora collections, detected on new host genera and families, but which otherwise are indistinguishable from Cercospora apii, should be avoided, and such collections should simply be referred to as $C$. apii s. lat.

Literature survey indicated that Cercospora moringae Thirum. \& Govindu has been described from Moringa oleifera. However, this species is not a true Cercospora and is currently accepted as Asperisporium moringae (Thirum. \& Govindu) Deighton (Crows \& Braun 2003). Hence, the present collection is treated as a new host record of Cercospora apii s. lat..

\section{Acknowledgements}

Authors are grateful to the Head, Department of Botany, DDU Gorakhpur University, Gorakhpur and Director, Birbal Sahni Institute of Palaeobotany for providing library and laboratory facilities. Author's thanks are also due to the Curator, HCIO, IARI, New Delhi for depositing the specimens and providing accession numbers and Uttar Pradesh State Biodiversity Board for assistant to first author. Authors are also thankful to Anonymous for critical review and useful suggestions to improve the manuscript.

\section{References}

Crous PW Braun U 2003 - Mycosphaerella and its anamorphs: 1. Names published in Cercospora and Passalora C.B.S. Utrecht. pp.571.

Kamal 2010 - Cercosporoid fungi of India, Bishan Singh Mahendra Pal Singh Publication, Dehradun (UK), India, pp. 351. 